\title{
Sugammadex use in difficult intubation due to ankylosing spondylitis and severe restrictive respiratory disease
}

\author{
Ankilozan spondilite bağlı ağır solunum yetmezliği ve zor entübasyon vakasında \\ sugammadex kullanımı
}

\author{
Yakup Tomak', Habib Bostan", Başar Erdivanlı², Ahmet Şen ${ }^{1}$
}

\begin{abstract}
We describe anesthesia management of a 50-year-old man scheduled for thoracic spinal reconstruction, presenting with severe restrictive respiratory disease and difficult airway due to ankylosing spondilitis. The patient was unable to extend his head, had difficulty in breathing and sleeping in supine position due to thoracal deformities. The patient was intubated using intubating laryngeal mask airway to overcome the difficulties of limited mouth opening and head extension. He was extubated following administration of sugammadex to obtain optimal conditions in terms of respiratory muscle function and to prevent hypersecretion and bronchospasm. J Clin Exp Invest 2012; 3 (3): 398-400
\end{abstract}

Key words: Restrictive lung disease, airway management, laryngeal masks, sugammadex, ankylosing spondylitis

\section{INTRODUCTION}

Ankylosing spondylitis (AS) is a chronic, progressive, otoimmune disease characterised by granulation tissue infiltration into ligaments and joint capsules. ${ }^{1}$ The male-to-female ratio of ankylosing spondylitis is $3: 1$. HLA-B27 genotype is expressed in approximately $90 \%$ of patients. In $40 \%$ of cases, the temporomandibular joint is involved, limiting mouth opening. ${ }^{2-4}$ Involvement of cervical spines limits head extension and can make intubation by direct laryngoscopy extremely difficult or impossible. ${ }^{1}$ Most common sites of involvement are sacroiliac joints and the spine.

Granulation tissue infiltration into joints causes difficulty in intubation. ${ }^{2-4}$ Several guidelines and suggestions are present in the literature aiding in management of difficult airway in AS patients. We

\section{ÖZET}

$\mathrm{Bu}$ yazıda, torasik spinal rekonstrüksiyon operasyonu planlanan, ankilozan spondilite bağlı ağır restriktif akciğer hastalığı ve zor entübasyon bulguları gösteren 50 yaşında erkek hastanın anestezi yönetimi tartışıldı. Torakal deformite nedeniyle hastanın baş ekstansiyonu kısıtlı, supin pozisyonda uyuma ve nefes almada zorluk çekiyor. Ağız açıklığında ve baş ekstansiyonundaki kısıtlılık nedeniyle hasta larengeal maske kullanılarak entübe edildi. Bronşiyal sekresyonlarda artış ve bronkospazmı önlemek, solunum kaslarının fonksiyonunu optimum düzeyde geri döndürmek için sugammadex uygulamasını takiben ekstübe edildi.

Anahtar kelimeler: Restriktif akciğer hastalığı, havayolu yönetimi, larengeal maske, sugammadex, ankilozan spondilit

presented a difficult intubation case carrying a risk of postoperative pulmonary insufficiency and discussed its management.

\section{CASE REPORT}

A 50-year-old man scheduled for posterior thoracic spinal reconstruction due to back pain. His medical history included AS for fourteen years, anatomical deformities beginning ten years before and severe restrictive lung disease. He took non-steroidal antiinflammatory agents to treat his back pain, had no history of allergy to any medication and smoked twenty cigarettes per day for 35 years. He was 168 $\mathrm{cm}$ tall and weighed $83 \mathrm{~kg}$, could not extend his head, and had difficulty in breathing in supine position. The anteroposterior diameter of his chest was increased. His mouth opening was two $\mathrm{cm}$, thyro-

${ }^{1}$ Rize Üniversitesi, Anesteziyoloji ve Reanimasyon Anabilim Dalı, Rize, Türkiye

${ }^{2}$ Rize Eğitim ve Araştırma Hastanesi, Anesteziyoloji ve Reanimasyon Kliniği, Rize, Türkiye

Correspondence: Başar Erdivanlı,

Rize Eğitim ve Araştırma Hastanesi, Anesteziyoloji ve Reanimasyon Kliniği, Rize, Türkiye Eposta: berdivanli@gmail.com 
mental distance was three $\mathrm{cm}$ and had a mallampathy score of four. Pulmonary function tests revealed FVC: 1869 ml (37\%), FEV1:1786(45\%), FEV1/FVC: $95 \%$ suggesting severe restrictive lung disease. Laboratory analysis revealed an arterial blood gas $\mathrm{pH}: 7.36, \mathrm{pO}_{2}: 60 \mathrm{mmHg}, \mathrm{pCO}_{2}: 43 \mathrm{mmHg}, \mathrm{SpO}_{2}$ : $94 \%$, erythrocyte sedimentation rate 60 in the first hour and C-reactive protein level of $3.1 \mathrm{mg} / \mathrm{l}$.

Due to thoracic spinal reconstruction, general anesthesia was planned. The patient rejected awake fiberoptic intubation and informed consent for a possible tracheotomy was obtained. Routine monitorization of electrocardiogram, $\mathrm{SpO}_{2}$ and noninvasive blood pressure was applied. Neuromuscular function was monitored using TOF-Watch®-SX (Organon, Dublin, Ireland). The patient was placed in the semi-fowler position and preoxygenated for 3 minutes using a tight fitting face mask while breathing $100 \%$ oxygen at a rate of $5 \mathrm{l} / \mathrm{min}$. Anesthesia was induced with propofol $2 \mathrm{mg} / \mathrm{kg}$ and fentanyl 1.5 $\mathrm{mg} / \mathrm{kg}$ intravenously (iv). Neuromuscular blockade was provided with rocuronium $0.6 \mathrm{mg} / \mathrm{kg}$ iv. Upon reaching a T1 value of $0 \%$ in TOF-Watch ${ }^{\circledR}-S X$, the patient was intubated using an intubating laryngeal mask airway (ILMA). Anesthesia was maintained with nitrous oxide/oxygen $\left(\mathrm{FiO}_{2}: 0.5\right)$ and sevoflurane $2 \%$ inspired concentration with controlled ventilation. Neuromuscular blockade was maintained with supplemental doses of rocuronium $0.15 \mathrm{mg} /$ $\mathrm{kg}$ iv while monitoring the state of neuromuscular function.

In the end of the surgery, which lasted approximately four hours, the patient was moved into the supine position. Upon reaching a T4/T1 ratio of $50 \%$, sugammadex $2 \mathrm{mg} / \mathrm{kg}$ iv was administered. T4/T1 ratio reached $90 \%$ in 85 seconds and the patient was extubated. After an uneventful period of two hours in the post anesthesia care unit, he was transferred to the surgical ward. He recovered well and was discharged from the hospital seven days later.

\section{DISCUSSION}

Ankylosing spondylitis resulting in granulation tissue deposition in ligaments and joint capsules, is a progressive form of inflammatory arthritis. Knee, hip and spinal reconstruction surgeries may be required in patients. While many of these procedures can be managed by regional anesthesia, cervical and thoracal reconstruction necessitates general anesthesia. ${ }^{5}$ Regional anesthesia was successfully used during caesarean sections and lower extremity procedures, although difficult to perform due to spinal deformities. ${ }^{6,7}$
Patients with AS are at significant risk for postoperative pulmonary complications. Thoracal deformities cause restrictive pulmonary disease. ${ }^{8}$ Radford and colleagues reported that mortality due to pulmonary complications is higher in AS patients. ${ }^{9}$ Therefore cervical and temporomandibular joint radiographs to evaluate airway, pulmonary function test and arterial blood gas analysis to predict postoperative respiratory complications and echocardiogram to detect cardiac abnormalities were ordered during preoperative period. ${ }^{1}$ Limitations of head extension and mouth opening can make intubation by direct laryngoscopy extremely difficult or impossible. Applying excessive force to extend the head during laryngoscopy may result in cervical and neurologic injury. This may be prevented by using an ILMA or flexible fiberoptic bronchoscope in cases where the patient rejects the safest option, which is awake intubation with local anesthesia. ${ }^{1} \mathrm{Lu}$ and colleagues reported that a total of 12 patients, each presenting with severe AS, were successfully intubated with ILMA. ${ }^{10}$

Although AS is not a disease of neuromuscular junction, residual neuromuscular blocking activity can be equally harmful for AS patients presenting with restrictive lung disease. Since our patient had a very low forced vital capacity, even a small amount of residual neuromuscular block could result in postoperative mechanical ventilation dependency. Therefore monitorization of neuromuscular function is required to prevent postoperative residual neuromuscular blockade. Nondepolarizing neuromuscular blocking agents are typically antagonized with cholinesterase enzyme inhibitors like neostigmine or pyridostigmine.$^{11}$ which may cause bradycardia, hypersalivation and bronchospasm. ${ }^{12}$ Their inability to reverse deep neuromuscular blockade also restricts their use..$^{13}$ Sugammadex is a y-cyclodextrine molecule designed to reverse neuromuscular blockade induced by steroidal nondepolarizing neuromuscular blocking agents. ${ }^{14}$ Sugammadex encapsulates the circulating rocuronium molecules and lowers its concentration in plasma and subsequently at the motor end plate, resulting in rapid reversal of neuromuscular blockade. ${ }^{15}$

We used sugammadex to completely reverse rocuronium-induced neuromuscular blockade and experienced no postoperative pulmonary complications, despite the presence of severe restrictive pulmonary disease. In conclusion, we suggest that ILMA can be used to intubate AS patients with difficult airway and sugammadex may be used to prevent postoperative residual neuromuscular blockade. 


\section{REFERENCES}

1. Woodward LJ, Kam PC. Ankylosing spondylitis: recent developments and anaesthetic implications. Anesthesia 2009; 64(5): 540-8.

2. Benimof JL. Management of the difficult airway. With special emphasis on awake intubation. Anesthesiology 1991; 75(9): 1087-110.

3. Raval C, Patel H, Patel P, Kharod U. Retrograde intubation in a case of ankylosing spondylitis posted for correction of deformity of spine. Saudi J Anesth 2010; 4(1): 38-41.

4. Hoh DJ, Khoueir P, Wang MY. Management of cervical deformity in ankylosing spondylitis. Neurosurg Focus 2008; 24(1): E9.

5. Kumar CM, Mehta M. Ankylosing spondylitis: lateral approach to spinal anesthesia for lower limb surgery. Can J Anaesth 1995; 42(1): 73-6.

6. Sivrikaya GU, Hanci A, Dobrucali H, Yalcinkaya A. Cesarean section under spinal anesthesia in a patient with ankylosing spondylitis-a case report. Middle East J Anesthesiol 2010; 20(6): 865-8.

7. Dougados M, Dijkmans B, Khan M,et al. Conventional treatments for ankylosing spondylitis. Ann Rheum Dis 2002; 61(3): 40-50.

8. Radford EP, Doll R, Smith PG. Mortality among patients with ankylosing spondylitis not given X-ray therapy. N Engl J Med 1977; 297(11): 572-6.

9. Lu PP, Brimacombe J, Ho AC, Shyr MH, Liu HP. The intubating laryngeal mask airway in severe ankylosing spondylitis. Can J Anaesth 2001; 48(10): 1015-9.
10. Osmer C, Vogele C, Zickmann B, Hempelmann G. Comparative use of muscle relaxants and their reversal in three European countries: a survey in France, Germany and Great Britain. Eur J Anaesthesiol 1996; 13(4): 389-99.

11. van Vlymen JM, Parlow JL. The effects of reversal of neuromuscular blockade on autonomic control in the perioperative period. Anesth Analg 1997; 84(1): 14854.

12. Booij LH, de Boer HD, van Egmond J. Reversal agents for nondepolarizing neuromuscular blockade: reasons for and development of a new concept. Sem Anesthesia Periop Med Pain 2002; 21(1): 92-8.

13. de Boer HD, van Egmond J, van de Pol F, Bom A, Booij LH. Chemical encapsulation of rocuronium by synthetic cyclodextrin derivatives: reversal of neuromuscular block in anaesthetized Rhesus monkeys. $\mathrm{Br}$ J Anaesth 2006; 96(2): 201-6.

14. Günay $H$, Başağan $E$, Kaya $F$, et al. Comparison of the efficacy of dexmedetomidine and esmolol in the treatment of increased hemodynamic response during the recovery period. J Clin Exp Invest 2012; 3(1): 53-60.

15. Bom A, Bradley M, Cameron K, et al. A novel concept of reversing neuromuscular block: chemical encapsulation of rocuronium bromide by a cyclodextrin-based synthetic host. Angew Chem Int Ed Engl 2002; 41(3): 266-70. 